\title{
PERAN WKS. KESISWAAN DALAM MENGEMBANGKAN EKSTRAKURIKULER DI SMK DARUSSALAM BLOKAGUNG TAHUN PEMBELAJARAN 2019/2020
}

\author{
Amirotun Nahdliyah ${ }^{1}$, Fathul Amin ${ }^{2}$ \\ e-mail: amirohnahdliyah@gmail.com ${ }^{1}$, nirmadsilva355@ gmail.com ${ }^{2}$ \\ Prodi Manajemen Pendidikan Islam \\ Insitut Agama Islam Darussalam Blokagung Banyuwangi
}

\begin{abstract}
Abstrak
Penelitian ini bertujuan untuk mengetahui dan mendeskripsikan peran manajemen kesiswaan dalam mengembangkan bakat siswa pada ekstrakurikuler dan untuk mengetahui fakor pendukung dan penghambat proses kegiatan ekstrakurikuler di SMK Darussalam Tahun Pembelajaran 2019/2020. Jenis penelitian yang digunakan merupakan jenis penelitian lapangan (field research) atau penelitian kualitatif. Metode yang digunakan adalah observasi, wawancara dan dokumentasi. Analisis data yang digunakan adalah deskriptif kualitatif, Sedangkan yang menjadi subjek penelitian adalah WKS. Kesiswaan dan penanggung jawab ekstra. Berdasarkan hasil penelitian dapat disimpulkan bahwa manajemen kesiswaan berperan positif dalam mengembangkan bakat siswa yaitu: pengontrol dan bertanggung jawab atas berjalannya ekstra, kegiatan ekstrakurikuler yang diadakan dapat meningkatkan bakat siswa dibidang seni. Hal ini terbukti dengan berbagai hasil prestasi yang telah capai siswa. Faktor pendukung: sebuah dukungan dari pihak sekolah sangat dibutuhkan dalam menunjang kelancaran pengembangan ekstrakurikuler di SMK Darussalam. Pihak sekolah di SMK Darussalam sangat mendukung penuh kegitan ekstrakurikuler baik dalam pemberian material dan fasilitas serta perizinan dalam melaksaksanakan kegiatan ekstrakurikuler. Faktor penghambat: Waktu pelaksanaan kegiatan ekstrakurikuler di SMK Darussalam dilaksanakan dengan mengambil jam aktif pembelajaran akhirnya kegiatan ekstrakurikuler dalam satu bulan hanya dilaksanakan dua kali agar tidak mengganggu kegiatan pembelajaran di SMK Darussalam.
\end{abstract}

Kata Kunci: Peran WKS. Kesiswaan, Pengembangan Ekstrakurikuler

\section{Abstract}

This study aims to determine and describe the role of student management in developing student talent in extracurricular activities and to find out the supporting factors and inhibitors of extracurricular activities in SMK Darussalam 2019/2020 academic year. This type of research is a type of field research or qualitative research. The method used is observation, interview and documentation. Analysis of the data used is descriptive qualitative, while the subject of research is the Student WKS. and extra responsibility. Based on the results of the study it can be concluded that student management has a 
positive role in developing student talent, namely: controlling and taking responsibility for extra walking, extracurricular activities held can increase student talent in the arts. This is proven by the various achievements that students have achieved. Supporting factors: a support from the school is needed to support the smooth development of extracurricular activities in Darussalm Middle School. Schools in Darussalam strongly support extracurricular activities both in the provision of materials and facilities as well as licensing in carrying out extracurricular activities. Inhibiting factors: The time for extracurricular activities in Darussalam is carried out by taking active hours of learning. does not interfere with learning activities in Darussalam.

Keywords: Educator Performance, Student Learning Motivation

\section{A. Pendahuluan}

Dalam pendidikan atau mendidik tidak hanya sebatas mentransfer ilmu saja, tetapi yang lebih utama adalah dapat mengubah atau membentuk karakter dan watak seseorang agar menjadi lebih baik, lebih sopan dalam tataran etika maupun estetika perilaku dalam kehidupan sehari-hari (Muslich, 2011: 47-48), pendidikan karakter menjadi salah satu harapan karena karakterlah yang menjadi penopang perilaku individu. Dalam Islam, karakter atau akhlak mempunyai kedudukan penting dan dianggap mempunyai fungsi yang vital dalam memandu kehidupan. Sebagaimana firman Allah SWT. dalam al-Qur'an surat at-Taubah ayat 122:

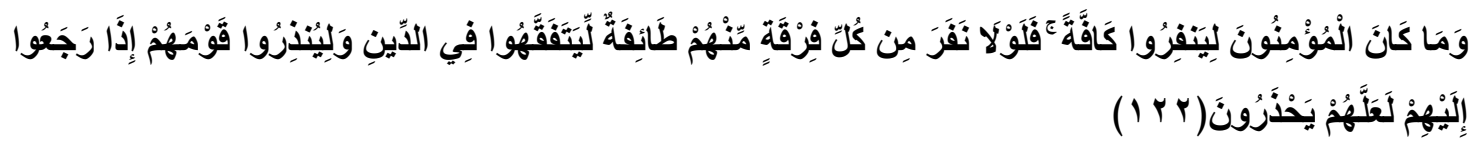

Artinya:"Tidak sepatutnya bagi mukmin itu pergi semuanya (ke medan perang). Mengapa tidak pergi dari tiap-tiap golongan di antara mereka beberapa orang untuk memperdalam pengetahuan mereka tentang agama dan untuk memberi peringatan kepada kaumnya apabila mereka telah kembali kepadanya, supaya mereka itu dapat menjaga dirinya. (QS. At-Taubah: 122)

SMK Darussalam adalah sekolah yang berbasis pesantren, selain itu visi dari sekolah adalah terwujudnya SMK bertaraf nasional dan menghasilkan lulusan yang 
cerdas, siap kerja dan kompetitif, dalam penelitian ini peneliti memberikan gambaran tentang pentingnya ekstrakulikuler yang dibina oleh kesiswaan sekolah, karena sesuai dengan permasalahan yang ada bahwa ekstra yang ada di sekolah SMK Darussalam masih belum maksimal karena waktunya sangat terbatas di karenakan sekolah yang notabennya di bawah naungan Yayasan Pondok Pesantren mempunyai kegiatan kepesantrenan yang sangat padat, di samping itu kerapnya kompetensi yang diadakan oleh sekolah luar dalam berbagai event yang ada, dan tak hanya itu kesiswaan berusaha mengoptimalkan kegiatan ekstra sebagai acuan agar para siswa siswi paham dan mengerti tentang pentingnya ekstra yang semestinya. Berbagai masalah yang ada di sekolah SMK Darussalam dengan mempertimbangkan adanya faktor penghambat dan faktor pendukung sehingga mengharuskan kesiswaan untuk mewajibkan para siswa siswi mengikuti kegiatan ekstra tersebut, diharapkan nantinya setelah keluar dari sekolah mampu mengembangkan ekstra ekstra yang lain khususnya.

Dengan adanya kegelisahan tersebut khususnya di sekolah SMK Darussalam dalam bidang ekstrakurikuler maka penulis memilih judul: "Peran Wks. Kesiswaan dalam Mengembangkan Ekstrakulikuler di SMK Darussalam Tahun Pembelajaran 2019/2020”. Manfaat pada penelitian ini adalah:

a. Manfaat teoritis

1) Memberikan sumbangan pemikiran dalam rangka meningkatkan kompetensi berfikir dan berimajinasi menegemukan teori yang ada bagi Peneliti, Sebagai media belajar dalam mengaktualisasikan pengalaman

2) Memberikan sumbangan dalam rangka penyempurnaan konsep

b. Manfaat praktis

1) Bagi peneliti, Sebagai media belajar dalam mengaktualisasikan pengalaman belajar dalam rangka berfikir kritis,logis,juga mempertajam analisis berfikir dan mebambah wawasan.

2) Bagi SMK Darussalam, sebagai bahan masukan dan bahan pertimbangan dalam proses pengambilan kebijakan lebih lanjut dalam rangka mengembangkan ekstrakurikuler melalui peran kesiswaan. 
3) Untuk menambah khazanah keilmuan terkait peran Wks. Kesiswaan dalam mengembangkan ekstrakurikuler.

\section{B. Metode Penelitian}

\section{Jenis dan Pendekatan Penelitian}

Penelitian ini merupakan jenis penelitian metode kualitatif, yaitu penelitian yang berlandaskan pada fisafat postpositivisme di mana kebenaran sesuai dengan hakikat obyek, digunakan untuk meneliti pada kondisi objek yang alamiah, di mana peneliti sebagai instrumen kunci dan hasil penelitian lebih menekankan makna dari pada generalisasi. (Sugiyono. 2007: 15). Pendekatan yang digunakan dalam jenis penelitian ini adalah pendekatan deskiptif, karena penelitian ini dilakukan secara naturalistik karena penelitiannya dilakukan dalam kondisi yang alamiah (natural setting).

\section{Sumber Data}

Dalam penelitian ini peneliti menggunakan sumber data berupa hasil observasi, hasil wawancara, dan dokumentasi tentang Peran Wks. Kesiswaan dalam Pengembangan Ekstrakurikuler di SMK Darussalam Tahun Pembelajaran 2019/2020. Menurut Lofland dalam Moleong (2006: 57) sumber data utama dalam penelitian kualitatif ialah kata-kata dan tindakan, selebihnya adalah data tambahan seperti dokumentasi dan lain-lain.

\section{Teknik pengumpulan Data}

Dalam penelitian ini teknik pengumpulan data menggunakan tiga tahapan sesuai dengan pendapat Sugiyono (2015: 309) menyatakan "dalam penelitian kualitatif pengumpulan data dilakukan pada natural setting (kondisi yang alami), sumber data primer dan teknik pengumpulan data lebih banyak pada observasi berperan serta, wawancara mendalam dan dokumentasi ".

\section{Teknik Analisis Data}

Analisis data dalam penelitian ini menggunakan teknik analisis data dalam situs yang dikembangkan oleh Miles and Huberman. Data yang sudah terkumpul 
dibuat dalam matriks. Dalam matriks akan disajikan penggalan-penggalan data deskriptif sekitar peristiwa atau pengalaman tertentu yang menyekat data sebelum dan sesudahnya. Setelah data dimasukkan ke dalam matriks selanjutnya dibuat daftar cek.

\section{Keabsahan Data}

Teknik yang digunakan dalam pemeriksaan keabsahan data seperti yang dikemukakan oleh Moleong (2006: 327), adalah perpanjangan keikutsertaan, ketekunan pengamatan, triangulasi, pengecekan sejawat, analisis kasus negative, kecukupan refrensial, dan pengecekan dengan anggota yang terlibat dalam penelitian. Pengujian keabsahan data menggunakan empat kriteria sebagaimana yang dikemukakan oleh Sugiyono, yaitu: kredibilitas (credibility), keteralihan (transferability), kebergantungan/reliabilitas (dependability), dan kepastian/dapat dikonfirmasi (confirmabilitiy).

\section{Hasil dan Pembahasan}

1. Data Terkait Peran Wks. Kesiswaan dalam Mengembangkan Ekstrakurikuler di SMK Darussalam

Berdasarkan hasil wawancara peneliti dengan Wks. Kesiswaan, keefektifan kegitan ekstrakurikuler di SMK Darussalam berdasarkan antusias siswa dan daftar hadir kegiatan ekstrakurikuler siswa baik di ekstra pramuka ataupun ekstra lainnya bisa dikatakan 70\%. Dari data tersebut bisa dikatakan sudah efektif, hanya sedikit hal yang perlu adanya kreasi dan inovasi untuk lebih meningkatkan kefektifan kegiatan tersebut. Di antara penunjang meningkatnya minat atau antusias siswa adalah banyaknya tawaran-tawaran untuk mengikuti event-event antar sekolah, sehingga siswa lebih semangat lagi dalam mengikuti kegiatan ekstrakurikuler.

Secara tidak langsung kegiatan ektrakurikuler bisa menjadi salah faktor penunjang kemajuan sekolah, karena dengan adanya ektrakurikuler akan 
memberikan peluang bagi peserta didikan untuk meraih prestasi baik akademik maupun non akademik. Jadi peran Wks. Kesiswaan di SMK Darussalam bisa dikatan sudah berjalan dengan baik, dengan memberikan dukungan dan tanggung jawab penuh dalam terselenggaranya kegiatan ekstarkurikuler di SMK Darussalam.

2. Data Terkait Faktor Pendukung dan Penghambat Peran Wks. Kesiswaan dalam Mengembangkan Ekstrakurikuler Ekstrakurikuler di SMK Darussalam

Adapun factor pendukung dan penghambat pengembangan ektrakurikuler berdasarkan hasil wawancara dan observasi di SMK Darussalam adalah sebagai berikut:

a. Faktor pendukung

Adanya dukungan penuh dari pihak sekolah sebuah dukungan dari pihak sekolah sangat dibutuhkan dalam menunjang kelancaran pengembangan ekstrakurikuler di smk darussalm. Pihak sekolah di smk Darussalam sangat mendukung penuh kegitan ekstrakurikuler baik dalam pemberian material dan fasilitas serta perizinan dalam melaksaksanakan kegiatan ekstrakurikuler.

b. Factor penghambat

1) Kurangnya waktu pelaksanaan ekstrakurikuler

2) Penyesuaian dengan peraturan pesantren Darussalam

Baik factor penghambat dan pendukung ini akan menjadi tantangan bagi SMK Darussalam khususnya kepada Wks. Kesiswaan untuk selalu berinovasi dan lebih kreatif lagi dalam pelaksanaan kegiatan ekstrakurikuler di SMK Darussalam agar perkembangan ekstrakurikuler di SMK Darusslam menjadi lebih baik lagi dan terus bisa bersaing dengan Lembaga Pendidikan yang lain dalam mengembangkan ekstrakurikuler, karna ekstrakurikuler merupakan salah satu factor pendukung agar Lembaga Pendidikan menjadi lebih maju. 
Pembahasan pada penelitian ini adalah sebagai berikut:

1. Peran Wks. Kesiswaan dalam Mengembangkan Ekstrakurikuler di SMK Darussalam

Peran menurut Soerjono Soekanto (2002: 243) yang menjelaskan apabila seseorang melaksanakan hak dan kewajibannya sesuai dengan kedudukannya. Manajemen kesiswaan bertujuan untuk mengatur berbagai kegiatan dalam bidang kesiswaan antara lain seperti ekstrakurikuler. Pengembangan ektrakurikuler di SMK Darussalam tidak lepas dari peran Wks. Kesiswaan sangat dibutuhkan karena Wks. Kesiswaan bertanggung jawab dan melakukan pengontrolan agar kegiatan ekstrakurikuler di SMK Darussalam bisa berjalan dengan baik. Dalam pelaksanaan progam ektrakurikuler Wks. Kesiswaan dibantu oleh kordinator ektrakurikuler dan pembina osis SMK Darussalam. Dalam satu semester kegitan ekstrakurikuler dievaluasi tiga kali dengan tujuan agar kegiatan ekstrakurikuler selalu berkembang.

Ekstrakurikuler di SMK Darussalam dibimbing oleh pembina yang telah sesuai dengan bidangnya agar peserta didik bisa lebih cepat memahami materi yang diberikan. Karena jika tidak dibimbing oleh pembina yang ahli maka akan terjadi sebaliknya, maka dari itu dibutuhkan orang-orang yang ahli dibidangnya dalam mengembangkan ekstrakurikuler di SMK Darussalam agar pengembangan ektrakurikuler di SMK Darussalam bisa berkembang dengan efesien dan efektif.

Tujuan adanya eksrakurikuler di SMK Darussalam yaitu untuk menyalurkan minat bakat peserta didik dalam bidang non akademik utamanya. Selain itu tujuan diadakan ekstrakurikuler di SMK Darussalam juga untuk melatih mental peserta didik untuk berani tampil dimuka umum, contohnya seperti ektrakurikuler public speaking.

Berdasarkan hasil wawancara peneliti dengan Wks. Kesiswaan, keefektifan kegitan ekstrakurikuler di SMK Darussalam berdasarkan antusias 
siswa dan daftar hadir kegiatan ekstrakurikuler siswa baik di ekstra pramuka ataupun ekstra lainnya bisa dikatakan 70\%. Dari data tersebut bisa dikatakan sudah efektif, hanya sedikit hal yang perlu adanya kreasi dan inovasi untuk lebih meningkatkan kefektifan kegiatan tersebut. Di antara penunjang meningkatnya minat atau antusias siswa adalah banyaknya tawaran-tawaran untuk mengikuti event-event antar sekolah, sehingga siswa lebih semangat lagi dalam mengikuti kegiatan ekstrakurikuler.

Secara tidak langsung kegiatan ektrakurikuler bisa menjadi salah faktor penunjang kemajuan sekolah, karena dengan adanya ektrakurikuler akan memberikan peluang bagi peserta didikan untuk meraih prestasi baik akademik maupun non akademik. Jadi peran Wks. Kesiswaan di SMK Darussalam bisa dikatan sudah berjalan dengan baik, dengan memberikan dukungan dan tanggung jawab penuh dalam terselenggaranya kegiatan ekstarkurikuler di SMK Darussalam.

2. Faktor Pendukung dan Penghambat Peran Wks. Kesiswaan dalam Mengembangkan Ekstrakurikuler di SMK Darussalam

Yang dimaksud dengan factor pendukung adalah semua factor yang sifatnya turut mendorong, menyokong, melancarkan, menunjang, membantu, mempercepat, dan sebagainya terjadinya sesuatu. Adapun yang dimaksud dengan factor penghambat adalah semua jenis factor yang sifatnya menghambat (menjadikan lambat) atau bahkan menghalangi dan menahan terjadinya sesuatu. Kemudian dalam kamus besar kata factor diartikan sebagai keadaan, hal atau peristiwa yang ikut mempengaruhi atau menyebabkan terjadinya sesuatu. Dalam pelaksanaan kegiatan pasti ada factor pendukung dan penghambat yang terjadi dalam suatu Lembaga Pendidkan. Adapun factor pendukung dan penghambat pengembangan ektrakurikuler adalah sebagia berikut:

a. Faktor pendukung 
Adanya dukungan penuh dari pihak sekolah sebuah dukungan dari pihak sekolah sangat dibutuhkan dalam menunjang kelancaran pengembangan ekstrakurikuler di SMK Darussalm. Pihak sekolah di SMK Darussalam sangat mendukung penuh kegitan ekstrakurikuler baik dalam pemberian material dan fasilitas serta perizinan dalam melaksaksanakan kegiatan ekstrakurikuler. Hal ini sangat membantu untuk mengembangkan kegiatan ekstrakurikuler di SMK Darussalam agar menjadi lebih baik lagi dan dapat bersaing dengan sekolah-sekolah lain yang ada di sekitar sekolah SMK Darussalam.

b. Factor penghambat

1) Kurangnya waktu pelaksanaan ekstrakurikuler

Waktu pelaksanaan kegiatan ekstrakurikuler di SMK Darussalam dilaksanakan dengan mengambil jam aktif pembelajaran akhirnya kegiatan ekstrakuler dalam satu bulan hanya dilaksanakan 2 kali agar tidak mengganggu kegiatan pembelajaran di SMK Darussalam. Hal ini sangat memperlambat kegiatan ekstrakurikuler untuk bisa berkembang dengan baik.

2) Penyesuaian dengan peraturan pesantren Darussalam

Dalam pembuatan progam kegiatan ekstarkurikuler tidak terlepas dari peraturan pesantren agar tidak terjadi kesenjangan social anatar pihak sekolah dengan pihak pesantren serta tatap terjalinya hubungan harmonis anatara keduanya.

Tapi di sisi lain hal ini malah menjadi penghambat perkembangan ektrakurikuler di SMK Darussalam menjadi lebih baik lagi, karna tidak semua minat bakat siswa bisa tersalurkan seperti kegiatan ekstrakurikuler tari, selain itu perizinan keluar pesantren yang sangat ketat membuat peserta didik untuk bisa menambah pengalaman merka di dunia luar. Akhirnya dari pihak sekolah memanfaatkan semua yang ada di sekolah agar kegiatan tetap bisa berjalan dengan dan tidak bersebelah dengan aturan pondok pesantren. 
Baik factor penghambat dan pendukung ini akan menjadi tantangan bagi SMK Darussalam khususnya kepada wks kesiswaan untuk selalu berinovasi dan lebih kreatif lagi dalam pelaksanaan kegiatan ekstrakurikuler di smk Darussalam agar perkembangan ekstrakurikuler di smk darusslam menjadi lebih baik lagi dan terus bisa bersaingan dengan Lembaga Pendidikan yang lain dalam mengembangakan ekstrakurikuler, karna ekstrakurikuler merupakan salah satu factor pendukung agar Lembaga Pendidikan menjadi lebih maju.

\section{Kesimpulan}

1. Peran Wks. Kesiswaan dalam mengembangkan ekstrakurikuler di SMK Darussalam Blokagung tergolong baik. Dalam melaksanakan fungsinya sebagai Wakil Kepala Sekolah telah mendukung keberhasilan program ekstrakurikuler dengan sangat baik. Tugas WKS kesiswaan adalah sebagai pengontrol dan bertanggungjawab atas berjalannya ekstrakurikuler. Bentuk dari pengontrol dan bertanggungjawab atas berjalannya ekstrakurikuler yaitu dengan mengontrol kegiatan atau Mengevaluasi dalam satu semester kegitan ekstrakurikuler dievaluasi tiga kali dengan tujuan agar kegiatan ekstrakurikuler selalu berkembang. Dan dalam melaksanakan tugas dann tanggungjawabnya, WKS kesiswaan telah melaksanakannya dengan baik dan sesuai perannya di lembaga pendidikan.

2. Faktor penghambat dalam melaksanakan kegiatan ekstrakurikuler di SMK Darussalam yaitu hanya bisa di lakukan satu minggu dua kali dengan cara mengambil jam efektif sehingga memperlambat kegiatan ekstrakurikuler untuk berkembang. tetapi kekuranagn itu tertutupi dengan adanya faktor pendukung yaitu adanya dukungan penuh dari pihak sekolah dalam melaksanakan kegiatan Ekstrakurikuler di 
smk Darussalam, terutama dalam hal material dan fasilitas. Sehingga kegiatan tetap terlaksana dengan baik. Saran pada penelitian ini yaitu:

a. WKS. Kesiswaan, Koordinator, Ekstrakurikuler dan Pembina Ekstrakurikuler SMK Darussalam diharapkan lebih bertambah semangatnya dalam mengawal, mendampingi, dan melatih minat bakat setiap peserta didik.

b. Kepada Sekolah SMK Darussalam untuk lebih kreatif dan inovatif dalam mengembangkan ekstrakurikuler.

\section{E. Daftar Pustaka}

Arikunto, Suharsimi. 2014. Prosedur Penelitian. Jakarta: Rineka Cipta

Emzir. 2010. Metodologi penelitian Kualitatif. Jakarta: Rajawali Pers

Imron, Ali. 2011. Manajemen Peserta Didik Berbasis Sekolah. Jakarta: PT. Bumi Aksara

John W. Creswell. 2006. Reaearch Design Pendekatan Metode Kualitatif, Kuantitatif, dan Campuran. Jakarta: Rajawali Pers

Minarti, Sri. 2016. Manajemen Sekolah. Jogjakarta: Ar-Ruzz Media

Prihatin, Eka. 2014. Manajemen Peserta Didik. Bandung: Alfabeta

Rizqa Dwi Seftiani, Sity Dieny Hafsoh, Irawan. 2018. Perencanaan Strategik. Bandung: Remaja Rosdakarya

Sedarmayanti T. 2017. Perencanaan dan Pengembangan Sumber Daya Manusia. Bandung: Refika Aditama

Peran Wks. Kesiswaan dalam Mengembangkan Ekstrakurikuler di SMK Darussalam Blokagung Tahun Pembelajaran 2019/2020

Amirotun Nahdliyah, Fathul Amin 
Vol. 3, No. 1: 112-123, April 2021

ISSN: 2722-7146 (Media Online)

Setiawan Edi, T. 2016. Implemementasi Penerimaan Peserta Didik Baru Sekolah

Menengah Atas Sisitem Real Time Online (RTO) Kabupaten Bantul. Yogyakarta:

Program Sarjana

Sugiono. 2015. Metode Penelitian. Bandung: Alfabeta

Strauss, Anselm. 2015. Dasar-Dasar Penelitian Kualitatif. Yogyakarta: Pustaka Belajar

Peran Wks. Kesiswaan dalam Mengembangkan Ekstrakurikuler di SMK Darussalam Blokagung Tahun Pembelajaran 2019/2020

Amirotun Nahdliyah, Fathul Amin 